\title{
Changes in Plasma $\gamma$-Glutamyl Transpeptidase Activity Associated with Alterations in Drug Metabolism in Man
}

\author{
J. B. WHITFIELD, D. W. MOSS, G. NEALE, M. ORME, A. BRECKENRIDGE
}

British Medical fournal, 1973, 1, 316-318

factor into the use of this enzyme test in the investigation of liver function (Whitfield et al., 1972). On the other hand, alterations in serum GGT may provide information regarding the activity of drug-oxidizing enzymes in the liver. Correct

\section{Summary}

A significant rise in plasma $\gamma$-glutamyl transpeptidase activity (GGT) was observed on 13 out of 14 occasions on which patients on long-term treatment with the oral anticoagulant warfarin were given amylobarbitone, quinalbarbitone, or phenazone (antipyrine) for 30 days. In 13 of these 14 studies there was evidence that drug administration had stimulated the rate of warfarin metabolism. One patient showed no increase in plasma GGT activity, yet a significantly increased rate of warfarin metabolism, and another patient showed an increase in plasma GGT activity without a change in warfarin metabolism. When alterations in both plasma GGT activity and plasma warfarin concentration occurred together in response to drug administration the changes followed a similar time course, occurring after about one week of drug administration with maximal changes at about 10 or 15 days. Administration of chlordiazepoxide, diazepam, nitrazepam, and methaqualone did not stimulate the rate of warfarin metabolism in four patients studied, but plasma GGT activity increased significantly in two of these four instances. The implications of these observations in the interpretation of plasma GGT activities are discussed.

\section{Introduction}

Many studies have shown that enzyme activity in the endoplasmic reticulum of the liver is markedly increased by administration of various drugs, hormones, or other chemicals (Conney, 1967). The greater activity appears to reflect an increased concentration of enzyme protein and is referred to as enzyme induction. This is of clinical importance because administration of inducing agents, such as barbiturates, can alter the duration and intensity of action of many drugs, including the oral anticoagulant warfarin, which are inactivated by microsomal enzymes. Direct proof of liver microsomal enzyme induction depends on showing that administration of an inducing agent results in an increase of enzyme activity in the liver. Indirect evidence comes from the finding of a shortening in plasma half-lives and lowered steady-state concentrations in the plasma of drugs metabolized by these enzymes, or from an increased rate of production of drug metabolites. Recently, increases in the activity of the enzyme $\gamma$-glutamyl transpeptidase (GGT) in human serum after administration of phenobarbitone and phenytoin have been reported (Rosalki et al., 1971; Whitfield et al., 1972) while administration of phenobarbitone to rats has been shown to be accompanied by an increased activity of this enzyme in liver tissue (Ideo et al., 1972).

The possibility of changes in serum GGT activity resulting from drug administration in man introduces a complicating

Royal Postgraduste Medical School, London W12 OHS J. B. WHITFIELD, PH.D., M.R.C.PATH., Senior Scientific Officer, Depart-
ment of Chemical Pathology

D. W. MOSS, PH.D., Reader in Enzymology, Department of Chemical

Pathology

M. ORME, M.B., M.R.C.P., Senior Registrar in Clinical Pharmacology A. BRECKENRIDGE, M.B., M.R.C.P., Lecturer in Clinical Pharmacology knowle of of altering serum GGT, possible dependence on dose, and the timecourse of drug-induced changes in serum enzyme activity. We have therefore investigated the relation between changes in plasma GGT and changes in the rate of metabolism of warfarin in patients given a series of hypnotic and sedative drugs.

\section{Patients and Methods}

Altogether 11 patients were investigated, four on more than one occasion. The ages of these patients, the reason for administration of warfarin, and the hypnotic or sedative studied are shown in the table. No patient was taking any other drug that would alter warfarin metabolism. Age, Reason for Administration of Warfarin, and Sedative or Hypnotic Drue
Given in the 11 Patients Studied

\begin{tabular}{|c|c|c|c|}
\hline $\begin{array}{l}\text { Case } \\
\text { No. }\end{array}$ & $\begin{array}{l}\text { Age and } \\
\text { Sex }\end{array}$ & $\begin{array}{l}\text { Clinical Indication for } \\
\text { Warfarin Therapy }\end{array}$ & $\begin{array}{c}\text { Sedatives and Hypnotics } \\
\text { Administered }\end{array}$ \\
\hline 1 & $40 \mathrm{M}$. & Deep vein thrombosis & \multirow{3}{*}{$\begin{array}{l}\text { Amylobarbitone, metha- } \\
\text { qualone, phenzone } \\
\text { (antipyrine) } \\
\text { Phenazone } \\
\text { Chlordiazepoxide, } \\
\text { quinalbarbitone } \\
\text { Diazepam, amylobarbitone } \\
\text { Amylobarbitone } \\
\text { Phenazone } \\
\text { Dichloralphenazone } \\
\text { Quinalbarbitone } \\
\text { Dichloralphenazone } \\
\text { Nitrazepam } \\
\text { Amylobarbitone }\end{array}$} \\
\hline 2 & $\begin{array}{l}52 \mathrm{M} . \\
55 \mathrm{M} .\end{array}$ & $\begin{array}{l}\text { Deep vein thrombosis } \\
\text { Rheumatic heart disease }\end{array}$ & \\
\hline $\begin{array}{r}4 \\
5 \\
6 \\
7 \\
8 \\
9 \\
10 \\
11\end{array}$ & $\begin{array}{l}57 \mathrm{M} . \\
60 \mathrm{M} . \\
54 \mathrm{~F} . \\
54 \mathrm{~F} . \\
55 \mathrm{~F} . \\
79 \mathrm{~F} . \\
54 \mathrm{M} . \\
55 \mathrm{~F} .\end{array}$ & $\begin{array}{l}\text { Deep vein thrombosis } \\
\text { Deep vein thrombosis } \\
\text { Deep vein thrombosis } \\
\text { Rheumatic heart disease } \\
\text { Deep vein thrombosis } \\
\text { Rheumatic heart disease } \\
\text { Deep vein thrombosis } \\
\text { Deep vein thrombosis }\end{array}$ & \\
\hline
\end{tabular}

Patients on long-term warfarin were studied for a control period of at least 30 days. During this time twice-weekly blood samples were taken with plastic syringes into sodium citrate $(10 \% \mathrm{v} / \mathrm{v})$. Plasma was stored at $-20^{\circ} \mathrm{C}$ until the analyses were carried out. Plasma warfarin concentrations were measured by the method of Lewis et al., (1970) and plasma GGT by the method of Szasz (1969). While continuing the same dose of warfarin the patient was given the drug under study, usually for a period of 30 days, and twice-weekly measurements were continued. Also, when the hypnotic was stopped, measurements were continued for at least four weeks. Informed consent was obtained from each patient for these investigations. In two patients the period of drug administration was increased to 60 days.

For both the plasma warfarin concentration and the plasma GGT activity the mean of four results before drug administration was compared with the mean of four results obtained during the last two weeks of drug therapy. These results were analysed by Student's $t$ test.

\section{Results}

A significant fall in plasma warfarin concentration was accompanied by a significant rise in plasma GGT activity $(P<0.01)$ on 13 out of 14 occasions (fig. 1). In these studies the fall in 


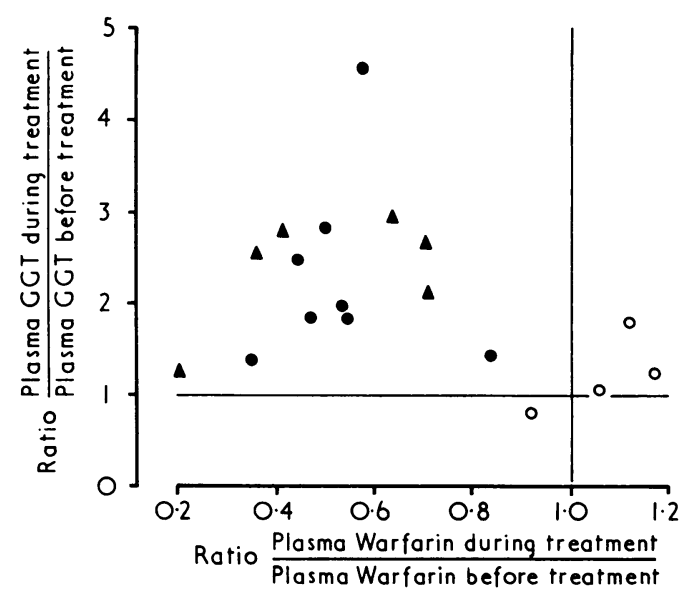

FIG. 1-Relation between changes in steady-state plasma warfarin concentration and plasma $\gamma$-glutamyl transpeptidase (GGT) in 11 patients given hypnotic or sedative drugs on 18 occasions. $O=$ Diazepam, nitrazepam, chlordiazepoxide, and methaqualone. $=$ Barbiturates. $\Delta=$ Dichloraphenazone and phenazone (antipyrine).

plasma warfarin and the rise in plasma GGT were roughly proportional. In seven out of 10 patients whose plasma GGT was normal before drug administration the rise in enzyme activity was great enough to cause the normal range to be exceeded. The enzyme activity was initially abnormal on the three other occasions on which drug administration produced a significant rise in plasma GGT. The time scale of both changes was very similar. Little change was seen in either value during the first week of drug administration and a maximum change occurred in about 10-15 days (fig. 2). After withdrawal of the drug, pretreatment levels were reached in 15-20 days. The drugs producing these changes were amylobarbitone (three studies), dichloralphenazone (one study), phenazone (four studies), quinalbarbitone (four studies), and phenazone with amylobarbitone (one study). There was a single exception to the usual finding that administration of enzyme-inducing drugs led to a rise in circulating GGT activity. In one patient (case 9) a four-fold change in plasma warfarin concentration during dichloralphenazone therapy was accompanied by a slight change in plasma GGT activity which was not statistically significant $(P>0 \cdot 1)$.

On four occasions nitrazepam, diazepam, chlordiazepoxide, or methaqualone was given and in all these studies there was no significant change in plasma warfarin concentration, but in two instances a significant rise in plasma GGT activity was seen. In one of these a patient (case 10) treated with nitrazepam showed a rise from an initially abnormal level of $30.9 \pm 1.6$ to $40.3 \pm 7.0 \mathrm{IU} / 1$. $(P<0.05)$ while in the other patient (case 1) given methaqualone plasma GGT rose from $14.4 \pm 1.4$ to $21.5 \pm 3.6 \mathrm{IU} / 1$. $(P<0.01)$. (This patient had
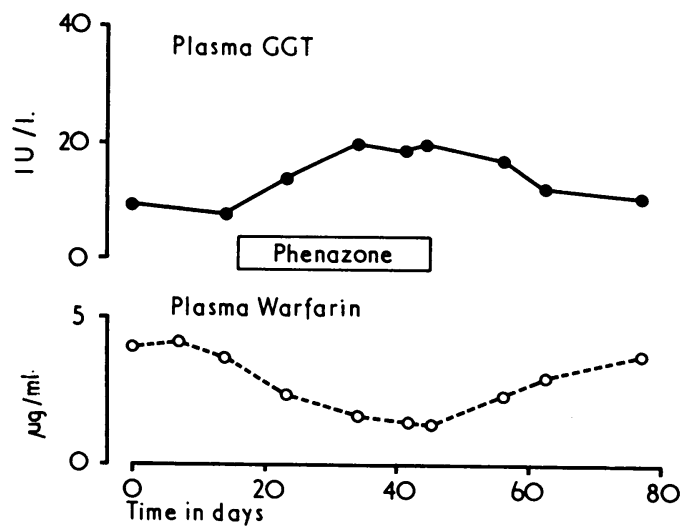

FIG. 2-Time-course of changes in plasma warfarin concentration and GGT activity in Case 6 during and after administration of phenazone (antipyrine). earlier shown a typical rise in plasma GGT on administration of phenazone and amylobarbitone.) In the two remaining studies with diazepam and chlordiazepoxide there was no significant change in either plasma GGT activity or plasma warfarin concentration.

Although most patients received inducing drugs for not longer than 30 days, there was evidence that both the GGT and the plasma warfarin concentration reached new steady state levels during this time. In two patients (cases 1 and 2) the period of drug administration was increased to 60 days.

In the first of these patients, initially given phenazone $300 \mathrm{mg}$ twice a day, the plasma warfarin concentration fell from $1.42 \pm 0.06$ to $0.98 \pm 0.07 \mu \mathrm{g} / \mathrm{ml}(P<0.01)$ while the plasma GGT activity rose from $19 \cdot 7 \pm 1 \cdot 2$ to $40 \cdot 0 \pm 3 \cdot 1 \mathrm{IU} / \mathrm{l}$. $(P<0.01)$. For the second 30 days amylobarbitone $200 \mathrm{mg}$ at night in addition to the phenazone caused both a further significant rise in plasma GGT activity (to $54 \cdot 2 \pm 5 \cdot 1 \mathrm{IU} / 1$., $P<0.01$ ) and a further fall in plasma warfarin concentration (to $0.50 \pm 0.06 \mu \mathrm{g} / \mathrm{ml}, \mathrm{P}<0.01$ ).

In the second patient the dose of phenazone was increased from $300 \mathrm{mg}$ twice daily to $600 \mathrm{mg}$ twice daily for the last 30 days. There was no further significant fall in plasma warfarin concentration nor an increase in GGT activity after the first 30 days of phenazone therapy.

In one patient (case 3) who was given quinalbarbitone at three dose levels on separate occasions, both the plasma warfarin concentration and the plasma GGT activity showed some evidence of a dose-dependent change (fig. 3). Quinalbarbitone $100 \mathrm{mg}$ at night caused no significant change in plasma warfarin concentration. However, a significant rise in GGT from $59.0 \pm 6.9$ to $72.5 \pm 3.7 \mathrm{IU} / 1$. was observed $(P<0.05)$. During administration of quinalbarbitone $200 \mathrm{mg}$ at night a further rise of plasma GGT activity to $100.0 \pm 10.9 \mathrm{IU} / 1$. $(P<0.01)$ was accompanied by a fall in plasma warfarin concentration from $2.97 \pm 0.25$ to $1.41 \pm 0.22 \mu \mathrm{g} / \mathrm{ml}(P<0.01)$. However, a subsequent increase in the dose of quinalbarbitone to $300 \mathrm{mg}$ produced no significant further fall in plasma warfarin concentration or further significant change in plasma GGT $(\mathbf{P}>0 \cdot 1)$.

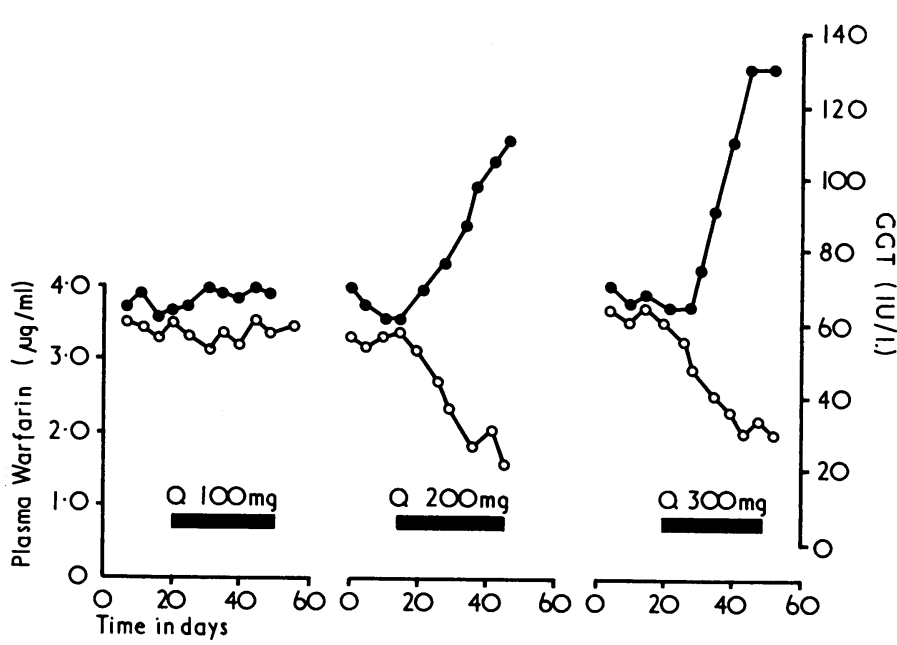

FIG. 3-Changes in plasma GGT and plasma warfarin in Case 3 given quinalbarbitone at three dose levels for 30 days. $=$ Plasma GGT. $O=$ quinalbarbitone at

\section{Discussion}

The day-to-day variation in plasma GGT activity in any one subject was found to be of the order of $10 \%$ and thus slight increases in activity associated with drug administration could be detected without difficulty. Increases in enzyme activity were found both in patients with normal plasma GGT activity and in those who had raised levels in the control period in 13 out of the 14 occasions on which drugs known to induce hepatic microsomal enzymes were given. 
It has been shown previously (Breckenridge et al., 1971; Breckenridge and Orme, 1971; Orme et al., 1972) that of the drugs studied dichloralphenazone, phenazone, quinalbarbitone, and amylobarbitone will increase the rate of warfarin metabolism while chlordiazepoxide, diazepam, nitrazepam, and methaqualone will not. This property was used as a marker in this study so that the time-course and extent of changes in plasma GGT activity could be compared with some changes in values known to reflect hepatic microsomal enzyme activity. It was found that the timing of the changes in plasma warfarin concentration was closely similar to that of changes in GGT activity. Both changes were observable by seven days, in most cases a plateau was reached after 10-15 days, and a return towards baseline values began immediately drug administration was stopped. It has been suggested previously that changes in serum GGT are found only after three months' treatment with inducing agents (Rosalki et al., 1971) but this was not confirmed in the present investigation.

Some evidence of a relation between drug dose and the increase in enzyme activity was also apparent. In those instances where a rise in GGT activity occurred, in over half the cases the increase took the GGT activity above the upper limit of normal. Thus the possibility of drug-induced changes in plasma GGT must influence the interpretation of raised GGT activities in suspected liver disease, especially when such raised levels occur unaccompanied by abnormalities in other tests of liver function (Whitfield et al., 1972).

Administration of three benzodiazepines, diazepam, nitrazepam, and chlordiazepoxide or methaqualone produced no change in steady state plasma warfarin concentration in four patients, but two of these patients showed a significant rise in plasma GGT activity. If these changes in plasma GGT activity reflect changes in the liver enzymes then these drugs may have caused an increase in liver GGT without an increase in the activity of enzymes concerned with drug oxidation. Alternatively, other factors, such as the effects of alcohol consumption, may have influenced GGT activity (Rosalki and Rau, 1972).

In view of these discrepancies between changes in rates of drug oxidation and plasma GGT activity, it appears that increases in the plasma GGT activity cannot always be used as an index of changes in the activity of liver microsomal enzymes concerned with drug oxidation since it might lead to both false-positive and false-negative results.

It remains to be proved that the increase in plasma GGT concentration produced by inducing agents is accompanied by an increase in hepatic GGT in man. Other possibilities are that other tissues such as the kidney or gut are the source of the increased plasma GGT or that the rate of catabolism of circulating GGT is altered or that these drugs produce hepatic damage of the type which is accompanied by an increase in plasma GGT activity in hepatobiliary disease. However, Rosalki et al. (1972) have reported that a wide range of serum enzymes other than GGT remained normal in patients in whom a raised serum GGT accompanied drug treatment. This last explanation, therefore, appears improbable. Ideo et al. (1972) have shown an increase in liver GGT content in rats treated with phenobarbitone, and our own preliminary observations support this.

Therefore, the most likely sequence of events seems to be that the induction of hepatic microsomal drug-metabolizing enzymes is accompanied by induction of hepatic GGT, which in most cases is released into the circulation. There may be differences between species, and individuals within a species, in the extent to which the GGT from the liver appears in the serum. The role of GGT in the liver and the effects of increased activity of this enzyme there are at present obscure.

\section{References}

Breckenridge, A., Orme, M. L'E., Thorgeirsson, S., Davies, D. S., and Brooks, R. V. (1971). Clinical Science, 40, 351 .

Breckenridge, A., and Orme, M. (1971). Annals of the New York Academy of Sciences, $179,421$.

Conney, A. H. (1967). Pharmacological Revierws, 19, 317.

Ideo, G., Morganti, A., and Dioguardi, N. (1972). Digestion, 5, 326.

Lewis, R. J., Inicki, L. P., and Carlstrom, M. (1970). Biochemical Medicine 4, 376.

Orme, M., Breckenridge, A., and Brooks, R. V. (1972). British Medical fournal, 3, 611 .

Rosalki, S. B., and Rau, D. (1972). Clinica Chimica Acta, 39, 41.

Rosalki, S. B., Rau, D., Tarlow, D., and Baylis, E. M. (1972). Proceedings of the 8th International Congress on Clinical Chemistry, Copenhagen.

Rosalki, S. B., Tarlow, D., and Rau, D. (1971). Lancet, 2, 376.

Szasz, G. (1969). Clinical Chemistry, 15, 124.

Whitfield, J. B., Pounder, R., Neale, G., and Moss, D. W. (1972). Gut, 13, 702 .

\title{
Morbidity from Acute Carbon Monoxide Poisoning at Three-year Follow-up
}

\author{
J. SIDNEY SMITH, S. BRANDON
}

British Medical fournal, 1973, 1, 318-321

\section{Summary}

Seventy-four survivors of acute carbon monoxide poisoning were followed up for an average of three years. In eight patients gross neuropsychiatric damage was directly attributable to the poisoning. Three patients had committed suicide and eight had died from other causes. Morbidity and mortality in those deliberately and accidentally poisoned was approximately equal.

\footnotetext{
University Department of Psychological Medicine, Royal Victoria Infirmary, Newcastle upon Tyne 1

J. SYDNEY SMITH, M.A.N.Z.C.P., D.P.M., Research Senior Registrar (Now Lecturer in Psychiatry, University of New South $W$ ales, Sydney, Australia) S. BRANDON, M.D., M.R.C. PSYCF., Nuffield Foundation Fellow in Psychiatry and Hononary Consultant Psychiatrist (Now Reader in Psychiatry, University of Manchester)
}

Of 63 patients alive at follow-up eight showed an improvement and $21(33.3 \%)$ a deterioration of personality after poisoning, and $27(43 \%)$ reported a subsequent impairment of memory. Deterioration of personality and memory impairment were highly correlated. The level of consciousness on admission to hospital in the acute phase of poisoning correlated significantly with the development of gross neuropsychiatric sequelae. These findings emphasize the importance of prompt and efficient treatment of carbon monoxide poisoning and the need to follow-up all cases in the anticipation of a relapsing course or the development of sequelae.

\section{Introduction}

Carbon monoxide (CO) acts pathogenically by displacing oxygen from the haemoglobin molecule, shifting the oxyhaemo- 